\title{
TYÖURA: YKSILÖN VALINTOJA VAI MONIMUTKAISTA KEHKEYTYMISTÄ?
}

Anu Järvensivu: FT, dos., yliopistonlehtori, Kasvatustieteiden laitos, Jyväskylän yliopisto

Jutta Pulkki: TtT, yliopisto-opettaja, Yhteiskuntatieteiden tiedekunta, terveystieteet, Tampereen yliopisto

anu.k.jarvensivn@jiu.fi,jutta.pulk.ki@tuni.fi

(U)

Janus vol. 27 (1) 2019, 38-54

Tiivistelmä

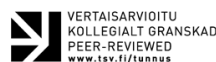

Artikkelissa tutkimme työurien kaaosteorian potentiaalia yhä moninaisemmiksi muuttuvien työurien ymmärtämisessä sekä työurien ja koetun terveyden välisten kytkösten hahmottamisessa. Kaaosteoria tuo esiin työurien erilaiset muodot ja niitä värittävät monenlaiset epävarmuudet, satunnaisuudet ja siirtymät. Aineistomme muodostuu kahdestatoista pohjoiskarjalalaisen miehen haastattelusta. Löysimme aineistosta kaikki teoriassa esitetyt neljä työuramuotoa, mutta ne limittyivät ja muoto saattoi myös vaihtua. Havaitsimme terveydentilan kytkeytyvän monisuuntaisesti työuran rakentumiseen, ja taloudellisten kysymysten välittävän kytköksiä. Esitämmekin, että yksilön vapaata valintaa ja lineaarista työuraa korostavien ajattelutapojen sijasta tutkimuksen ja poliittisen päätöksenteon tulisi ennemmin perustua käsitykseen työurien monimutkaisesta kytkeytyneisyydestä ja kontekstiin sitoutuneisuudesta.

\section{JOHDANTO}

Globalisaatio, muuttuvat teknologiat sekä taloudelliset, kulttuuriset, poliittiset ja sosiaaliset muutokset vaikuttavat tällä hetkellä työelämään. Työn murros näkyy pirstoutuneina työurina, hajaantuneina työnteon paikkoina ja useina samanaikaisina toimeentulon lähteinä sekä monenlaisten katkosten lisääntymisenä (Dufva ym. 2017). Jopa kokonaisten ammattien on ennakoitu katoavan lähivuosina aiheuttaen tarvetta varautua tilanteeseen erilaisin pätevyyksin ja uudelleenkoulutuksin (Frey \& Osborne 2013). Työsuhdemalleista pienyrittäjyys, sivutoimiyrittäjyys ja itsensätyöllistäminen ovat lähteneet kasvuun (Pärnänen \& Sutela 2013), vaikka toisaalta tilastoja katsoen perinteinen kokoaikainen palkkatyö on osoittautunut varsin pysyväksi (Pyöriä 2017).

Työtä pieniksi paloiksi silppuavan alustatalouden merkitys täysin uudenlaisena työn ja toimeentulon mallina herättää huolta muun muassa ammattijärjestöissä. Alustoilla syntyvän joukkoistetun työn on myös esitetty pakenevan työelämäntutkijoiden perinteisï lähestymistapoja (Alasoini 2017). Muutostutkijat ovatkin huomauttaneet murroksen olevan mittaluokaltaan uusia lähestymistapoja, metodeja ja käsitteistöjä vaativan; jopa työn käsitettä on ehdotettu määriteltäväksi uudelleen (esim. Järvensivu 2010; Dufva ym. 2017). 
Muuttuvan työelämän kehyksessä kansallista politiikkaa määrittävät vahvasti työllisyyden lisäämiseksi tarkoitetut toimet. Juha Sipilän hallituksen yhtenä kärkihankkeena on ollut työn vastaanottamiseen liittyvien kannustinloukkujen purkaminen sekä osallistava sosiaaliturva (Ratkaisujen Suomi 2015). Näistä teemoista puhuttaessa niin poliittisissa keskusteluissa kuin mediassakin on korostettu työttömien vastuuta ratkaisuistaan. Toisaalta monissa puheenvuoroissa on kyseenalaistettu työttömien mahdollisuudet tehdä itsenäisiä valintoja työn suhteen yhä monimutkaisemmaksi käyvässä ympäristössä. (Taloussanomat 13.12.2016; 16.2.2017; kansalaisaloite 2730.)

Keskustelu työttömyydestä kulminoitui vuodenvaihteessa 2017-2018 hallituksen lanseeraamaa "aktiivimallia" vastustavaan kansalaisaloitteeseen, joka ylitti nopeasti eduskuntakäsittelyn edellyttämän $50 \quad 000$ allekirjoittajan rajan. Aktiivimallin perusajatuksena on, että työttömän tulee taloudelliset sanktiot välttääkseen tietyllä aikavälillä joko onnistua hankkimaan tuloa palkkatyöstä tai yrittäjänä tai osallistua työllistymistä tukeviin toimiin. Kansalaiskritiikin kärki kohdistui siihen, ettei tämä ole kaikille työttömille mahdollista monista heistä riippumattomista tekijöistä johtuen. Kansalaisaloitteessa todetaan, että laki aktiivimallista "rankaisee kansalaista asioista jotka eivät ole hänen päätettävissään.” (kansalaisaloite 2730.)

Artikkelissa kyseenalaistamme työuran rakentamiseen liittyvän vapaan valinnan ajatuksen tuomalla esiin työurien monimuotoisuuden ja uralla tapahtuvien siirtymien monimutkaisuuden ja kontekstisidonnaisuuden. Nostamme tarkasteluun työuran rinnalle erityisesti terveyden valottaen näiden välisten kytkösten dynamiikkaa ja osoittaen yksilöstä riippumattomien tekijöiden vaikutuksen työurien muodostumiseen.

Käytämme haastatteluaineiston teorialähtöisessä analyysissa apuna työurien kaaosteoriaa, jota ei tietääksemme ole Suomessa aiemmin sovellettu. Tavoitteenamme on tuoda työurakeskusteluun uudenlainen lähestymistapa, tarkastella sen soveltuvuutta aineistossamme sekä sen avulla analysoida ja kuvata työurien ja terveyden moninaista luonnetta ja keskinäistä kytkeytyneisyyttä. Tutkimustehtävänä on ensinnäkin selvittää, ovatko haastateltujen työurat kuvattavissa ja ymmärrettävissä työurien kaaosteorian mukaisella jaottelulla ja millaisia työuramalleja aineiston tapauksista muodostuu. Toiseksi analysoimme, millaisia kytköksiä haastateltujen eri logiikoilla muotoutuvilla työurilla on heidän terveyskokemuksiinsa.

\section{LINEAARISUUDEN OLETUKSESTA}

Työuria ja terveyttä on usein tapana tarkastella suunnitellun lineaarisen prosessin tuloksina (Resnicow \& Page 2008). Tähän liittyy vahvasti ajatus yksilöiden vapaudesta ja mahdollisuuksista valita. Ihmisten ajatellaan tekevän rationaalisia $\mathrm{ja}$ vaikuttavia valintoja $\mathrm{ja}$ päätöksiä niin työuriinsa kuin terveyteensä liittyen. Tiukan tulkinnan mukaan rationaalisen ihmisen oletetaan punnitsevan tarkoin valintansa hyviä ja huonoja puolia, tekevän älykkään ratkaisun ja lopuksi toimintasuunnitelman päämäärän saavuttamiseksi (Resnicow \& Page 2008). Monissa yhteyksissä on 
jo tunnustettu, että valintoja tehdessään ihmistä kuvaa ennemmin näennäinen (taloustieteen nobelisti Richard Thaler teoksissaan) tai rajoitettu (taloustieteen nobelisti Herbert Simon teoksissaan) kuin tiukasti käsitetty rationaalisuus. Rationaalisuuden voi tulkita myös siis väljemmin niin, että siinä otetaan huomioon ihmisen elämismaailman sidonnaisuudet (Hechter \& Kanazawa 1997).

Zygmunt Bauman (1997) on yksi niistä keskeisistä ajattelijoista, jotka muistuttavat valinnanmahdollisuuksien historiallisista, kontekstuaalisista ja sosiaalisista sidonnaisuuksista. Baumanille kyky päättää ja tehdä valintoja on vapautta, mutta tätä valinnanvapautta rajoittavat niin muut ihmiset ja kulttuuriset sitoumukset kuin omat aikaisemmat valinnat. Se millaiseksi esimerkiksi työuramme muotoutuu ja määräytyy siitä, kenen lapseksi synnymme, millaisessa ympäristössä elämme ja millaisia päätöksïä olemme aikaisemmin elämässämme tehneet. (Bauman 1997, 29-48.) Yksilön mahdollisuus muusta elämismaailmasta irralliseen ja suoraviivaiseen valitsemiseen työuralla vaikuttaa tähän nähden harhalta.

Yhtä kaikki, aikamme yhteiskuntajärjestyksen ja poliittisen päätöksenteon, kuten aktiivimallin, taustalta voi edelleen tunnistaa suoraviivaisuusoletuksen sekä oletuksen yksilön valinnanmahdollisuuksista, ja Taylorin (1995) käsittein atomistisen individualismin mukaisen ihmiskäsityksen. Tämän mukaan ihminen on autonominen historiallisista ja situationaalisista siteistä vapaa ja irrallaan toimiva subjekti (Pulkki ym. 2015), oman elämänsä, työnsä ja terveytensä suhteen aktiivinen ja suoraviivainen toimija.
Kun ihmiselle sälytetään vastuuta asioista, joihin hänellä ei ole vaikutusmahdollisuuksia, syntyy yliautonomisoinnin vaara. Yliautonomisointi tarkoittaa yliyksilöllisten tilanteiden - kuten yhteisön, kulttuurin ja historian - sivuuttamista ja yksilön mahdollisuuksien yliarviointia. (Pulkki ym. 2015, 2015 162-163; vrt. Bauman 1997, 29-48.) Työttömien aktiivimalli on yksi esimerkki yliautonomisoinnista. Yliautonomisoinnin vaara syntyy, kun työuraa ja terveyttä kuvataan lineaarisina ja rationaalisina prosesseina. Ihmisen valintoja kontekstoivat ja rajoittavat tekijät jäävät huomiotta, valinnoista tulee näennäisiä ja epäonnistumisen seuraukset jäävät yksilön kannettavaksi (Pulkki ym. $2015,2015,169)$. Samoin toisiaan vahvistavat tai kumoavat takaisinkytkennät tai monimutkaiset seurausvaikutukset jäävät marginaaliin. (Amundson ym. 2014; Pryor \& Bright 2014.)

Työ ja terveys eivät ole puhtaasti yksilön valittavissa eivätkä yksilön "omaisuutta", vaan ne kietoutuvat monikerroksisiin yhteisöllisiin käytäntöihin, toisiin ihmisiin ja toisiinsa. Terveyteen vaikuttaa ihmisen omien valintojen lisäksi lukuisa joukko ihmiskehon mekanismeja, joita ihminen ei tiedosta, saati että voisi niihin aktiivisesti vaikuttaa. Näiden ohella tunnetaan vielä moninaisempi ja monitasoisempi terveyteen vaikuttavien ulkoisten tekijöiden joukko aina sikiöaikaisista elinoloista globaaleihin ympäristötekijöihin asti. (Diez Roux 2011; Fink ym. 2016.) Näistä sosiaalisista terveyden determinanteista eli terveyteen vaikuttavista tekijöistä johtuen sairaudet eivät ole useinkaan omilla valinnoilla suoraan ja lopullisesti estettävissä (Fink ym. 2016). 
Vastaavasti ihmisen rationaalisia valinnanmahdollisuuksia työuraansa helposti yliarvioidaan unohtaen, että työuriin vaikuttavat monet eritasoiset tekijät. Ihmisen - aktiivisten ja passiivisten - valintojen lisäksi toiset ihmiset, monenlaiset kontekstitekijät ja sattuma muokkaavat työuraa. Lineaarisen ja suunnitelmallisen työuran sijaan urapolut sisältävät usein monenlaisia mutkia ja vaihtoehtoja. (Pryor \& Bright 2012; 2014.) Terveys ja työurat ovat molemmat tulosta ihmisen ja ympäristön yhteen kietoutuneista monivaiheisista ja enemmän tai vähemmän ennustamattomista prosesseista. Tällainen kuva työstä ja terveydestä haastaa yksinkertaisia lineaarisia malleja sekä yksilön valinnanvapauden varaan rakentamista työhön ja terveyteen liittyvissä politiikkatoimissa.

Terveyden ja työurien epälineaarista ja ennustamatonta kehkeytymistä voidaan ymmärtää soveltamalla niihin kompleksisten systeemien teorioita (Pryor \& Brigth 2012; 2014; Beurden ym. 2011; Resnicow \& Page 2008), kuten kaaosteoriaa. Työurien kaaosteoria tarjoaa vaihtoehdon perinteisille työurateorioille ja mallinnuksille. Erilaisia systeemiteorioita on sovellettu runsaasti myös terveyden tutkimuksessa (Mingers \& White 2010), mutta työuran kaaosteorian kaltaista kehikkoa ei ole muodostunut (Fink ym. 2016).

\section{TyöUrat KaAOSTEORIAN Valossa}

Kaaosteorian valossa työura piirtyy kompleksiseksi ja epälineaarisesti eteneväksi. Kaaosteorian työurasovellus on kehitetty työuratutkimukseen vastauksena työelämän murrokseen (vrt. Dufva ym. 2017; Frey \& Osborne 2013; Pärnänen \& Sutela 2013). Perinteiset työuran lineaarisuutta ja suunniteltavuutta korostavat urateoriat sopivat yhä heikommin yhteen monimutkaistuneen ja jatkuvasti muuntuvan työelämän kanssa. Tästä syystä työn ja persoonan tai omien intressien yhteensopivuuden löytämistä korostavista teorioista, elämänkaariteorioista sekä selkeän päämäärän asettamista painottavista teorioista on siirrytty narratiivisiin ja metaforia käyttäviin teoriakehittelyihin, suunnitelmallisten onnellisten sattumien hyödyntämisen teoriaan sekä kompleksisuusteorioiden sovelluksiin. (Amundson ym. 2014.)

Työuran kaaosteorian tavoitteena on huomioida riittävällä tavalla työuran kehkeytymiseen vaikuttavat kontekstitekijät, kuten toisten ihmisten toiminta, asuinseudun piirteet, ihmisen tausta sekä satunnaisuudet. Teoriassa korostetaan, että ihminen ajattelee ja toimii todellisuuden ennakoitavan ja ennakoimattoman rajapinnassa ollen sekä looginen suunnittelija ja päätöksentekijä että valmis reagoimaan yllätyksiin ja sattumiin, joiden merkitys työuralle on todettu varsin isoksi. Työura kehkeytyy systeemisessä kontekstissa, jota luonnehtivat eri tekijöiden väliset monisuuntaiset kytkeytyneisyydet, jatkuva heikosti ennakoitavissa oleva muutos sekä epävarmuudet, satunnaisuudet ja suunnittelemattomat tapahtumat. Tämän kaltaisten työurien maailmassa valinnan mahdollisuudet ovat rajallisia. Ihmisten ajatellaan kuitenkin toiminnallaan pyrkivän sekä selviytymiseen että tarkoituksen ja mielekkyyden löytämiseen. (Pryor \& Bright 2014.) Ihmiset kehittävät ja käyttävät erilaisia pärjäämisstrategioita niin vastaantu- 
leviin tilanteisiin reagoidakseen kuin proaktiivisesti ja luovastikin (Järvensivu 2010). Tuloksena on kontekstissaan sidoksellisesti kehkeytyvä työura, joka jälkeenpäin kuvattuna voi näyttää suunnitelmallisemmalta kuin mitä se on todellisuudessa ollut.

Tutkimuksemme kannalta tärkeitä kaaosteorian käsitteitä ovat attraktorit ja siirtymät. Attraktorilla tarkoitetaan juonta tai logiikkaa, joka kompleksisuuden keskellä kehkeytyy ihmisen työuraa jäsentäväksi. Attraktorin kuvaus on ihmisen, hänen kontekstinsa ja töidensä muodostaman systeemin toimintalogiikan kuvaus. On olemassa erimuotoisia attraktoreja. Niille antavat muotoa ihmistä puoleensa vetävät, houkuttavat seikat, jotka voivat olla hyvinkin erilaisia ja niiden määrä vaihdella. Siirtymä taas tarkoittaa radikaalia muutosta työuralla ja ilmenee usein katkoskohtana. Siinä myös ihmisen työuraa jäsentävä muoto eli attraktori voi muuttua, jolloin siirtymässä tapahtuu hyppäys attraktorimallista toiseen. (Pryor \& Bright 2014.)

Työurien kaaosteorian mukaan työurat kehkeytyvät usein jollain taulukkoon 1 kootuista neljästä logiikasta (Amundson ym. 2014; Pryor \& Bright 2014).

Taulukko 1. Työuria jäsentävät logiikat ja attraktorimuodot työurien kaaosteorian mukaan.

\begin{tabular}{|c|c|}
\hline $\begin{array}{l}\text { Suoraviivainen } \\
\text { työura } \\
\text { (point attractor) }\end{array}$ & $\begin{array}{l}\text { Työura, jossa ihminen suuntautuu selkeästi yhteen tiettyyn päämäärään, } \\
\text { kuten ammattiin tai hierarkkiseen asemaan, niin ajatuksissaan kuin } \\
\text { teoissaankin. Tässä mallissa esiintyy usein tavoitteellisuutta, mutta se ei } \\
\text { ole välttämätöntä. On mahdollista, että jälkeenpäin suoraviivaiselta ja } \\
\text { tavoitteelliselta vaikuttava työura ei ihmisen omasta mielestä ole ollut } \\
\text { tavoitteellinen, vaan se on sisältänyt paljon vaihtoehtoja, vaikeita } \\
\text { valintoja ja sattumaa. }\end{array}$ \\
\hline $\begin{array}{l}\text { Heilurimallinen } \\
\text { työura } \\
\text { (pendulum } \\
\text { attractor) }\end{array}$ & $\begin{array}{l}\text { Työura, jossa ihmisen ajattelu ja toiminta on kahtia jakautunutta ikään } \\
\text { kuin heiluen kahden kiintopisteen välillä. Kiinnostuksen kohteet ja } \\
\text { pyrkimykset jakautuvat kahtaalle tai valintaa pitää tehdä kahden hyvin } \\
\text { erilaisen vaihtoehdon välillä. Tähän malliin saattaa liittyä ristiriitoja, } \\
\text { roolikonflikteja ja vaikeita valintoja. Toisaalta heiluri voi muodostaa } \\
\text { tasapainoisen kokonaisuuden, jossa sen eri päädyt täydentävät toisiaan. }\end{array}$ \\
\hline $\begin{array}{l}\text { Hahmonsa } \\
\text { löytävä työura } \\
\text { (torus attractor) }\end{array}$ & $\begin{array}{l}\text { Monimutkaisesti rakentuva työura, jossa kuitenkin näkyy toistuvuutta. } \\
\text { Työura saattaa piirtyä kehämäiseksi. Kompleksisuus ja ennakoitavuus } \\
\text { vuorottelevat tai tasapainottelevat. Muutosten seasta hahmottuu rutiineja, } \\
\text { tapoja ja järjestelmällisyyttä. Malli ja siihen sisältyvä toistuvuus ja } \\
\text { pysyvyys saattavat olla empiirisessä tutkimuksessa vaikeita havaita. }\end{array}$ \\
\hline $\begin{array}{l}\text { Hahmoton } \\
\text { työura (strange } \\
\text { attractor) }\end{array}$ & $\begin{array}{l}\text { Työura rakentuu hyvin monimutkaisesti eikä mallia tai juonta ylläpitävää } \\
\text { attraktoria löydy tai juoni muuttuu hyvin nopeassa tahdissa. Työurassa } \\
\text { saattaa tässäkin tapauksessa olla toistuvuuksia jollain tasolla. }\end{array}$ \\
\hline
\end{tabular}




\section{Aineisto Ja ANALYysi}

Tutkimusaineisto koostuu 12:sta sanatarkasti litteroidusta noin tunnin kestäneestä teemahaastattelusta, jotka on kerätty vuonna 2015 Koneen Säätiön Jakautuuko Suomi -ohjelman hankkeessa Terveyden luokkakuva.

Haastatellut ovat Pohjois-Karjalasta kotoisin olevia 1960-1968 syntyneitä miehï. Haastateltavat rekrytoitiin Sanomalehti Karjalaisessa julkaistulla lehtiartikkelilla. Haastateltavat ilmoittautuivat vapaaehtoisiksi keskustelemaan mm. työurasta, terveyden kokemisesta, Pohjois-Karjala-projektiin liittyvistä muistoista sekä talouteen liittyvistä huolikokemuksista. Tutkimukselle on pyydetty Helsingin yliopiston eettisen ennakkoarvioinnin toimikunnan lausunto.

Analyysimenetelmänä käytettiin vertailevaa tapaustutkimusta (Campbell 2012). Vertailevassa tapaustutkimuksessa on mahdollista käyttää lähtökohtana analyyttista kehystä (Goodrick 2014), joka tässä tutkimuksessa on työurien kaaosteoria. Tutkimus on siis teorialähtöinen (Tuomi \& Sarajärvi 2002). Tarkastelimme haastatteluja omina kokonaisuuksinaan etsien niiden sisäistä juonta ja logiikkaa eli attraktoria. Tapauksia vertailtiin eri työuramalleihin luokiteltaessa.Vertailu auttoi löytämään toisaalta samankaltaiset logiikat ja toisaalta erilaiset juonet. Se auttoi myös tunnistamaan eri työuramallien rajapinnat. Analyysin lopputulemana oli kunkin haastateltavan työuramalli ja tähän limittyvä koetun terveydentilan luonnehdinta.
Molemmat tutkijat analysoivat kuusi haastattelua, mutta kumpikin luki kuitenkin kaikki haastattelut useamman kerran. Analysoimme haastattelut ensin työurien näkökulmasta työurien kaaosteorian edellä esitettyä jaottelua apuna käyttäen. Keskustelimme yhdessä useita kertoja jaottelun perusteista sekä eri tapausten luokittelusta varmistaaksemme luokituskriteerien yhtenäisyyden.

Luokituskriteereinä käytimme toisaalta attraktoreita, eli uralta löytyneitä jatkuvuuksia ja houkuttavuuden kohteita sekä toisaalta siirtymiä, joita uralla tapahtui. Suoraviivaiseksi luokittelimme työuran, jolla siirtymiä oli vähän ja työura kiinnittyi yhteen pisteeseen. Heilurimalliseksi taas luokittelimme työuran, joka kiinnittyi kahtaalle, eli heilurille löytyi kaksi eri syistä houkuttelevaa päätepistettä. Hahmonsa löytäväksi työuraksi taas luokittelimme työuran, joka rakentui monenlaisista osista ja tapahtumista. Sille mahtui useita siirtymiä, mutta siitä löytyi myös koossapitäviä tekijöitä, jatkuvuuksia ja logiikoita. Sen sijaan hahmottomaksi työuraksi määrittelimme työuran, josta ei kiinnittävää attraktoria löytynyt, mutta siirtymiä oli runsaasti.

Luokittelun jälkeen tutkimme, mitä haastatellut kertoivat terveydestään. Pyrimme hahmottamaan elämänkaarelle sattuneita terveyden muutoksia, suhteuttamaan niitä työuran attraktoreihin ja siirtymiin sekä näin rakentamaan työuran rinnalle eräänlaista "terveysuraa". Havaitsimme työurien ja terveysurien välillä yhteyden siinä, miten kompleksisesti ne rakentuivat. 
Seuraavaksi analysoimme erilaiset elämäntilanteet, epävarmuudet, ristiriitaisuudet ja satunnaisuudet tarkastellen niitä sekä kontekstitekijöinä että dynamiikkoina. Tässä analyysivaiheessa huomasimme erityisesti haastateltavien taloushuolien kiertyvän sekä työhön että terveyteen. Muut työuraa muotoilevat tekijät rajasimme tutkimuksen ulkopuolelle, mutta niiden (esim. perhe, sosiaaliset suhteet, sosio-ekonominen asema ja alue) vaikutuksia on aineistosta havaittavissa.

Huomasimme, että suoraviivaisemmasta työurasta kertova kertoi usein myös terveydestä yksinkertaisemmin. Se saattoi johtua erosta kertomisen tapojen välillä, mikä jää omanlaisekseen riskitekijäksi tutkimukseen. Kyse on yhdestä laadullisen tutkimuksen perusdilemmasta ja ratkaisun paikasta: lähestyäkö haastattelu- tai kirjoituspyyntöaineistoa kerrontana vai kertomisen sisältöinä (ks. esim. Järvensivu 2014; Marttila 2015). Tässä tutkimuksessa orientaatiomme on realistinen tai faktuaalinen (Tuomi \& Sarajärvi 2002), eikä kerronnallinen (Aaltonen \& Leimumäki 2010; Alasuutari 2011, 125-141).

Haastateltujen yksityisyyden suojaamiseksi olemme tehneet tekstissä pieniä muutoksia esimerkiksi ammatteihin ja paikannimiin sekä korvanneet sitaateista yksityiskohtaisia ilmaisuja abstraktimmilla.

\section{TulOKSET}

Haastateltujen työ- ja terveysurien pääpiirteet ja kaaosteorian mukainen luokittelu on kuvattu taulukossa 2. Huomionarvoista on, että osa haastateltujen työurista asemoituisi luontevimmin luokkien väliin (taulukossa "välimuodot") ja vielä useammissa tapahtui siirtymiä uramallista toiseen. Tämä kuvastaa työurien kehkeytymisen kompleksisuutta.

Löysimme aineistosta kaikki työuran muodot - suoraviivainen työura, heilurimallinen työura, hahmonsa löytävä työura ja hahmoton työura - vaikka työuramalleissa olikin limittyneisyyttä. Joidenkin haastateltujen työuralla tapahtui siirtymiä, joissa työuramallikin näytti muuttuvan. Yksi tutkimuksen tuloksista onkin, että ihmisen työura ei välttämättä noudata koko ajan samaa mallia eivätkä mallit erotu toisistaan selväpiirteisesti.

Työurien ja työuramallien suhteutus haastateltujen koettuun terveydentilaan ja sen vaihteluihin paljasti, miten monisuuntainen kytköksellisyys työn ja terveyden välillä on. Työ määrittää terveyttä ja terveys työtä. Havaitsimme myös, että taloudelliset seikat sekä erityisesti työhön, talouteen ja sairauksiin liittyvät huolikokemukset vaikuttivat niin ikään työn ja terveyden välisiin kytköksiin monimutkaistaen asetelmaa edelleen. Näiden havaintojen valossa mahdollisuudet vapaaseen rationaaliseen valitsemiseen työtehtävien ja terveyden riskitekijöiden osalta rajautuvat sekä toisiinsa että muihin tekijöihin.

Suraviivainen työura, suoraviivainen terveys?

Neljän haastatellun työura eteni melko lineaarisesti. Jälkikäteen tarkasteltuna suoraviivaista uraa voisi pitää tavoitteiden mukaan etenevänä, päämäärähakuisena ja tietoisten valintojen tuottee- 
Taulukko 2. Haastatellut työuran attraktorimuotojen mukaan jaoteltuina.

\begin{tabular}{|c|c|}
\hline \multicolumn{2}{|l|}{ Suoraviivainen työura } \\
\hline Kirvesmies & $\begin{array}{ll}\text { - } & \text { Selkeä ura samalla alalla, vain muutama työpaikka. } \\
\text { - } & \text { Joitakin sairauksia; ei kuitenkaan huolia terveydestä. } \\
\text { - } & \text { Työttömyysaikoina kokenut taloudellista huolta, ei enää. }\end{array}$ \\
\hline Yrittäjä & $\begin{array}{ll}\text { - } & \text { Selkeä ura samalla alalla, nyt yrittäjänä, ollut myös muiden palveluksessa. } \\
\text { - } & \text { Työperäinen stressi, joka mm. valvottaa. Joitakin "pikkuvikoja", koettu terveys kuitenkin } \\
\text { hyvä. }\end{array}$ \\
\hline Tutkija & $\begin{array}{ll}\text { - } & \text { Selkeä ja katkeamaton työura samalla alalla. } \\
\text { - } & \text { Kokee ajautuneensa alalle, ei toiveammatti. } \\
\text { - } & \text { Työssä kiire ja istuminen koettelevat terveyttä, terveys on kuitenkin "perushyvä", ei } \\
& \text { sairauksia. } \\
\text { - } & \text { Ei työttömyyttä eikä taloudellista huolta. }\end{array}$ \\
\hline Opettaja & $\begin{array}{ll}\text { - } & \text { Selkeä ja katkeamaton työura samalla alalla, koulutusta vastaava ja tavoitteiden mukainen. } \\
\text { - } & \text { Työyhteisöt vaihtuneet, osa niistä koetellut henkistä jaksamista. } \\
\text { - } & \text { Perussairauksia, koettu huono kunto. }\end{array}$ \\
\hline \multicolumn{2}{|l|}{ Heilurimainen työura } \\
\hline $\begin{array}{l}\text { Koneteknikko/ } \\
\text { Maa- ja metsätalous } \\
\text { Suoraviivaisen ja } \\
\text { heilurimallisen työuran } \\
\text { välimuoto }\end{array}$ & $\begin{array}{ll}\text { - } & \text { Melko selkeä työura koneteknikkona, mutta maa- ja metsätalouskiinnostus seurannut } \\
\text { mukana. } & \\
\text { - } & \text { Tasapainottava heiluri. } \\
\text { - } & \text { Joitakin sairauksia, hallinnassa. } \\
\text { - } & \text { Ei taloudellista turvattomuutta. }\end{array}$ \\
\hline $\begin{array}{l}\text { Sähkömies/ } \\
\text { Maanviljelijä } \\
\text { Siirtymä suoraviivaisesta } \\
\text { heiluriuralle }\end{array}$ & 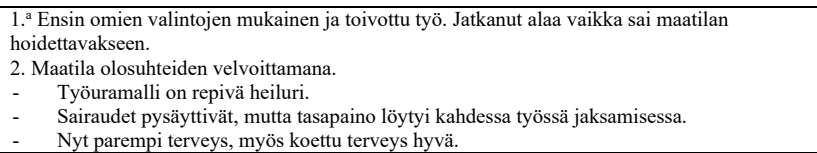 \\
\hline $\begin{array}{l}\text { Virkamies } \\
\text { Siirtymä suoraviivaisesta } \\
\text { heiluriuralle. }\end{array}$ & $\begin{array}{l}\text { 1. Koulutusta vastaava ura päättyi terveysongelmiin, minkä vuoksi joutui vaihtamaan alaa } \\
\text { mielekkääksi kokemastaan työstä. } \\
\text { 2. Toinen työurakin selväpiirteinen ja jatkuva, mutta tyytymätön työn sisältöön. } \\
\text { - Työurassa repivää heiluria, koska toiveena olisi toisenlainen työ. } \\
\text { - } \quad \text { Joitakin sairauksia, mutta hallinnassa. } \\
\text { - } \quad \text { Taloudellinen huoli estää uratoiveen toteutumisen. }\end{array}$ \\
\hline $\begin{array}{l}\text { Tutkija/ Maa- ja metsätalous } \\
\text { Työura tasapainottavassa } \\
\text { heiluriliikkeessä }\end{array}$ & $\begin{array}{l}\text { 1. Tutkija, muttei identifioidu tutkijaksi. } \\
\text { 2. Rakentaminen ja maa-ja metsätalous sivujuonteina, nyt harrastuksena, vaikka ihanneammatti. } \\
\text { - Tutkijan työssä mielenterveyden uhkia, metsätyö ja tutkijan työ tasapainottavat } \\
\text { terveysmielessä. } \\
\text { - } \quad \text { Ei taloudellisia huolia enää, mutta ollut epävarmuutta. }\end{array}$ \\
\hline $\begin{array}{l}\text { Opettaja-Näyttelijä } \\
\text { Heilurimallisen ja hahmonsa } \\
\text { löytävän työuran välimuoto }\end{array}$ & $\begin{array}{l}\text { 1. Opettaja/ohjaaja } \\
\text { 2. Näyttelijä } \\
\text { - } \quad \text { Työura monipolvinen, mutta melko selkeä ja tasapainoinen. } \\
\text { - } \quad \text { Työn luonteen vuoksi ollut runsaasti työpaikkoja. } \\
\text { - } \quad \text { Myös työn ja terveyden välinen suhde ristiriitainen: toisaalta työ tukee terveyttä, toisaalta } \\
\text { kuormittaa. } \\
\text { - Taloudellisia huolia toisinaan. }\end{array}$ \\
\hline \multicolumn{2}{|l|}{ Hahmonsa löytävä työura } \\
\hline Maanviljelijä-Rakennusmies & $\begin{array}{ll}\text { - } & \text { Työura sirpaleinen: useita siirtymiä koulutuksista, työtehtävistä ja työttömyysjaksoista } \\
\text { - } & \text { Haiseen. } \\
\text { - } & \text { Työaittavissa jatkuvuutta maanviljelijän ja osittain myös rakennusmiehen ammateissa. } \\
\text { - } & \text { Terveyden kokee hyväksi. } \\
\text { - } & \text { Taloudelliset huolet vaikuttavat mielen hyvinvointiin. Epävarmuus työstä kytkeytyy } \\
& \text { terveyteen taloudellisten huolten välityksellä. }\end{array}$ \\
\hline \multicolumn{2}{|l|}{ Hahmoton työura } \\
\hline $\begin{array}{l}\text { Monista tehtävistä } \\
\text { yrittäjäksi } \\
\text { Heikosti hahmottuva työura } \\
\text { (välimuoto) }\end{array}$ & $\begin{array}{ll}\text { - } & \text { Työura sirpaleinen ja sisältää monia ammatteja, tehtäviä, työpaikkoja, koulutuksia. } \\
\text { - } & \text { Työuran alussa lineaarista ylenemistä, lopulta päätyminen yhteisyritykseen. Muilta osin ei } \\
\text { selvää jatkuvuutta uralla. } \\
\text { - } \quad \text { Terveydellisiä uhkakokemuksia ja korjausliikkeitä. } \\
\text { - Talousmielessä huolehtija. }\end{array}$ \\
\hline $\begin{array}{l}\text { Monitoimijasta } \\
\text { työkyvyttömyys- } \\
\text { eläkkeelle }\end{array}$ & $\begin{array}{ll}\text { - } & \text { Työura hahmoton sisältäen useita erilaisia ammatteja, työpaikkoja ja koulutuksia. } \\
\text { - } & \text { Välillä erittäin hyvässä asemassa, myös taloudellisesti. } \\
\text { - } & \text { Lopulta työkyvyttömyyseläkkeellä. } \\
\text { - } & \text { Nyt taloudellisia vaikeuksia. }\end{array}$ \\
\hline
\end{tabular}

a numerot 1.ja 2. viittaavat kahteen eri työuraa. 
na. Toisaalta suoraviivainen työurakin saattoi kehkeytyä ajautumisten tai reagointien kautta. Esimerkkinä suoraviivaisesta työurasta ja sen terveydellisistä kytkennöistä esitämme kirvesmiehen tapauksen.

"Ei mulla kyllä oo ollu sen kummemmin haaveita, nuorempana. Se vaan silloin aikoinaan tuntui hyvältä. Että tää se on se juttu ja tässä on menty."

Kirvesmies oli toiminut alalla koko ikänsä ja hänen suhtautumisensa työhön ja uravalintaan oli mutkaton. Hän ei esittänyt vaihtoehtoja tai pohtinut valinnan onnistuneisuutta. Vastaavalla tavalla suoraviivaisesti kirvesmies luonnehti terveyttään. Selässä oli ollut pientä vaivaa, jota hän koki pystyvänsä pitämään hallinnassa liikkumista ja painoa säätelemällä.

"Jotain pikku kulumissii, olihan siellä, mutta ei mitenkään. Siellä oli aina niitä hermopinteitä, että se painos niitä."

Fyysisen työn kirvesmies esitti toisaalta terveyttä tukevaksi mutta toisaalta ikääntymisen myötä myös haasteeksi terveydelle. Taloushuolia oli miehen uran alkupuolella esiintynyt. Erityisesti lama-aikoina rakennustöitä oli pätkissä.

"Sitä oli vähän silleen pätkittäin sitä, ku sitten välillä oli aina töitä."

Myöhemmin huolet olivat helpottaneet. Kirvesmies kuitenkin tunnisti työuransa olevan jo lähellä sitä pistettä, jossa olisi mietittävä, miten pitkään fyysisesti vaativaa työtä jaksaa täysipainoisesti. Tässä kohdassa taloushuolet nousivat vaihtoehtoja rajaaviksi.
"No onhan sitä jo nyt tullu vähän mietittyä, että tai on jo ehottaneetkin tuolla työterveys että,jos tulloo sen jaksamisen kanssa, että jos tekis lyhy-, kevennettyy työviikkoo. Mutta ku siihen nyt ei ihan yks kaks. Ku se taas sitten vaikuttaa noihin vuosilomiin ja palakkaan. Mutta et joskin se on otettava sitten uuestaan työn alle, jos tuntuu siltä, että terveys esimerkiksi vaatii sen, niin totta kai sitten. Mutta ei ainakaan vielä, mutta kyllä niitä kannattaa jo märehtiä ja pähkäillä."

Kun peruslogiikaltaan suora ja selkeäpiirteinen työura soljui tasaisesti eteenpäin, taloushuolia ei ollut, mutta katkoksen mahdollisuus nosti huolet pintaan. Työn ja terveyden välinen kytkös oli selvä, muttei yksiselitteinen. Kirvesmiehen työ sekä edisti että vaaransi terveyttä ja työuran loppupäässä heikentynyt terveys vaaransi työuran jatkon. Suoraviivaisessa työuramallissa vaihtoehtoisia töitä tai ammatteja ei ollut muodostunut, joten valittavat vaihtoehdot olivat vähissä (vrt. Järvensivu 2014).

\section{Heiluria työssä, heiluria terveydessä?}

Heilurimallisesta työurasta esiintyi aineistossa kaksi toisistaan poikkeavaa variaatiota. Kolmen haastateltavan työurassa oli repivyyttä kahteen suuntaan, kun taas kahdella heiluriliike oli ennemmin toisiaan täydentävien tai tasapainottavien attraktoripisteiden välistä. Tapauksissa oli limittyneisyyttä.

Tutkijan tapaus edustaa tasapainottavaa ja täydentävää heilurimallista työuraa, jossa heilurin kumpikin päätepiste vetää puoleensa tarjoten toisiinsa nähden lisäarvoa elämänkokonaisuuteen. 
"No, työurasta nyt on ehkä paha sanoo. Elämähä heittelee."

Jo nuorena tutkijaa vetivät puoleensa maanviljely ja rakennustyöt. Hän totesi kuitenkin, ettei saavuttaisi näillä haluamaansa elintasoa. Tutkijaksi mies koki ajautuneensa sattumien kautta. Hän ajatteli itsensä "ihmeellise onnekkaaksi" saatuaan määräaikaisuuksien ja työttömyysjaksojen jälkeen tutkijoille harvinaisen vakipaikan. Sattumat ja onnenpotkut olivat muokanneet työuraa. Tutkijuuteen ei kohdistunut itsestään selvää attraktiota.

"Ei minusta mitään semmosta nyt ehkä perinteistä yliopistoihmistä muotoudu."

Nuoruuden ammatillisista haaveista kumpuavat rakentelu ja metsänhoito olivat säilyneet tutkijalla koko elämän tärkeinä ja mieluisina harrastuksina. Elämän kiinnekohdaksi hän ilmoitti harrastustensa paikan, kotitilan.

"Se lapsuuden maisema... Vesistöje äärelle kasvanu ni se on siellä se järvi, järvi ja metsä. ... En minä tiä, että en ymmärrä, minkä takia täällä viitsis elossa kestää, jos ei siellä olis. Tai kävis."

Kotimetsä ja metsätyöt pitivät "elossa", ja tutkijan työ antoi ajoittaisista epävarmuuksista huolimatta sen sosioekonomisen statuksen ja turvan, joka haastatellulla oli toiveena. Hän piti tutkijan työtään myös mielekkäänä, mutta terveyden näkökulmasta hieman kaksijakoisena.

"Tän turvallisempaa työtä, työtapaturmien mielessä ja terveyden ylläpidon mielessä ei oo kuin tää tutkijanhomma.

... Tää ei oo edes istumatyötä, että voi jalotella millon haluaa. Ainut on se, että kestääkö pää, eli leviääkö pää jostakin syystä, niin ku nytkin on yt-neuvottelut menossa ja tämmönen murros ja muutos ja epävarmuus."

Metsä ja rakentelu tarjosivat tutkijantyölle vastapainoa sekä fyysisessä että psyykkisessä mielessä. Vastaavasti tutkimustyö tarjosi metsä- ja rakentelutöihin täydentävyyttä taloudellisen turvan ja korkeamman sosio-ekonomisen aseman mielessä. Työuran heiluriliike oli tasapainottavaa. Myös terveys ja talous tasapainottuivat heiluriliikkeessä eivätkä huolet epävarmuuksista huolimatta leimanneet tutkijan tarinaa.

Toinen esimerkki heilurista on maanviljelijä-sähkömiehen ura. Kaksi ammattia repivät haastateltua välillä hyvinkin rankasti. Haastateltu mies oli työskennellyt sähkömiehenä, kunnes hänen kotitilaa pitänyt sukulaisensa kuoli. Sähkömies päätti ottaa tilan vastuulleen. Hän pyrki aluksi yhdistämään nämä kaksi uraa täysipainoisesti.

"Minä hoidan oman työni, ja minä hoian tän tilan. Eihän sitä jaksa kukaan. Siis minä yritin, varmaan sen vuos puoltoista siinä tosissaan. Ja sitten [tuli yllättävä sairauskohtaus]. Mää yritin yötä päivää tehä töitä, mie olin ihan burnoutissa, henkisesti ja fyysisesti. Opettelin niitä töitä mutta, sitte, oikeestaan se sairaus pysäytti."

Työuran repivyys näkyi terveysongelmina. Maanviljelijä-sähkömies ei siirtynyt pois kummastakaan ammatista, vaan vähensi töitään molemmissa. Tilanne tasapainottui, vaikkei yhtä hyvään synergiaan kuin tutkijalla. Maanviljelijä-sähkömiehen tapaus on esi- 
merkki työuraa kehystävien seikkojen dynamiikasta: satunnainen tapahtuma vaikutti perustavanlaatuisesti työuraan, repivä heiluriliike haittasi terveyttä ja terveyden vuoksi oli taas sopeutettava työuraa. Valinnanvapauden tila oli kapea.

Kolmas esimerkki heilurimaisesta työurasta on virkamiehen ura, jossa nykyinen työ on pakon sanelemaa ja oma kiinnostus ja arvostus kohdistuvat toisaalle. Myös tästä seurasi ristiriitainen ja repivä tilanne. Tilanteeseen ajautuminen johtui terveysongelmista, jotka pakottivat lopettamaan ensimmäisessä ammatissa. Siinä ura oli edennyt suoraviivaisesti koulunpenkiltä pitkäaikaiseen työsuhteeseen.

"...tää on tämmönen pakkotilanne. Pohjois-Karjalassa yli viisikymmentävuotias ku on mies, ei oo hirveesti valinnanmahdollisuuksia. On hieno asia, että on työpaikka, mutta tämä ei todellakaan oo mittään kauheen uljasta hommaa."

Virkamies koki työnsä vaihtoehdottomaksi.Vaikka sekä nykyisessä että aikaisemmassa työssään virkamies koki auttavansa ihmisiä, arvosti hän aikaisempaa työtään, nykyistä ei. Hän toivoi voivansa konkreettisemmin auttaa muita, mutta koki tämän vaihtoehdon taloudellisesti mahdottomaksi valinnaksi.

"Minä halluisin tehä semmosta kolmannen sektorin työtä esimerkiks. Tehä talavet metsätöitä ja autella noita kylän mummuja tehä niille lumitöitä ja polttopuita ja tämmöst. Mutta siitä ei kukkaan maksa."
Perintötilansa metsätöissä, koneita korjatessaan, nikkaroidessaan ja osallistuessaan yhdistystoimintaan harrastuspohjalta virkamies pääsi toteuttamaan unelmiaan, jotka vetivät häntä puoleensa. Kotitilan metsätyöt muodostivat tässäkin tapauksessa tasapainottavan tekijän.

Virkamiehen sysäsi heilurimaiseen työuraan terveydentilan muutos nivoen työ- ja terveysurien siirtymät tiukasti toisiinsa. Työuran teki repiväksi heiluriksi se, että haastatellun toiveet ja odotukset olivat ristiriidassa hänen terveytensä, taloutensa, ikänsä ja asuinalueensa johdosta pakon sanelemaksi kokemansa palkkatyön kanssa. Edellinen työ ja harrastukset rakensivat mielikuvaksi heilurin toisen päätepisteen, jonka mies mielellään valitsisi. Se jäi talouden ja terveyden vuoksi saavuttamattomaksi haaveeksi, mutta toisaalta sitä oli ajoittain harrastuksissa mahdollista lähestyä. Tässä tapauksessa harrastukset eivät tasapainottaneet, vaan lisäsivät kaipausta. Täyttymättä jääneet toiveet ja vaihtoehdottomuus työssä vaikuttivat puolestaan mielen hyvinvointiin.

\section{Hahmonsa löytävä työura ja terveys}

Maanviljelijä-puusepän työuramallin saattoi nimetä hahmonsa löytäväksi. Tämä työura eroaa heilurista siinä, että siirtymiä koulutusten ja työpaikkojen välillä oli useita, samoin työuran katkoksia. Siirtymien vuoksi muotoa oli aluksi vaikea hahmottaa haastattelusta. Silti työura ei ollut kaoottinen, vaan perintönä saatu maatila ja erilaiset työtehtävät puusepän ammatissa antoivat uralle jatkuvuutta. Työura etsi malliaan useita vuosia ja kehkeytyi lopulta kahdeksi yhteen kietoutuneeksi poluksi. 
Myös mielen hyvinvoinnin voi nähdä etsivän ja paikoin löytävänkin ratansa.

Haastatellun työuralle mahtui monia töitä, kuten virkamies-, opetus- ja neuvontatehtäviä agronomian alalla sekä useita erilaisia rakennusalan tehtäviä. Erityistä attraktion kohdetta ei löytynyt. Maanviljelijä-puuseppä ei kerro nuorenakaan haaveilleensa mistään ammatista eikä ole "... sillä tavalla asettanu oikeastaan tavoitteita."

Vaikka puusepän työhistoria oli katkonainen ja vailla urasuunnitelmaa, siihen oli haastatteluhetkellä löytynyt tasapaino sisältäen puusepän töitä sekä maatilan ylläpitämistä. Maanviljely oli puusepälle aikanaan myös kokopäivätyötä, mutta siitä ei saanut riittävää toimeentuloa eikä se turvannut eläkettä.

”..työ olisi tärkeä, koska ei tästä maatila...hommasta ei siitä saa semmosta toimeentuloa että sillä mitenkään pärjäis. Pakko on olla, palkkatyössä että sitten joskus sais jotain eläkettäkin."'

Puusepän urassakin oli pätkätöiden ja työttömyysjaksojen vuoksi omat epävarmuutensa. Työttömyysjaksojen aikana hän oli kouluttautunut ja muuttanut töiden perässä. Työttömyyden tuomaan taloudelliseen epävarmuuteen haastateltu oli sopeutunut karsimalla kulutustaan. Haastateltu ei asettanut suuria toiveita työnsä jatkuvuuteen, muttei suhtautunut tilanteeseensa alistuenkaan.

"...työttömyys on liittynyt, tai semmosen kautta kun tässä on muutenkin ollu työttömyyttä muillakin ihmisillä. Ei se ole pelkästään minulle sattunut se työttömyys. Se on yhteiskunnan ongelma sitten. Mut en nyt tiedä sitten mistä, mullakin tuo nykyinen työ ehkä loppuu tossa ihan kohtapuoleen."

Mielen hyvinvointiin auttoi työttömyysjaksojen aikana maatilan pakolliset tehtävät sekä harrastustoiminta, jolla haastateltu kertoi saavansa ajatukset pois työttömyydestä. Terveydellistä huolta aiheuttivat lisäksi yllättävät laihtumiset sekä unettomuus, joihin haastateltava mainitsee syyksi muun muassa kiireet töissä. Työhön tai työttömyyteen maanviljelijä-puuseppä ei liittänyt muita terveyshuolia, päinvastoin, hän koki fyysisen terveytensä tukevan työssäjaksamista.

"...mä olen aika hoikka ja kuitenkin oon liikkunu kaiken aikaa, totta kai se edesauttaa työssäjaksamista."

Taloudellinen epävarmuus oli puusepällä vaikuttanut niin työhön kuin terveyteenkin liittyviin päätöksiin. Epävarmuudet työssä vaikuttivat taloudellisten huolten välityksellä terveysuraan. Tämä näkyi epävarmuuden hetkellä, mutta huolet saattoivat kaventaa myös tulevaisuuteen suuntaavan ajattelun horisonttia - toiveita oman työn ja terveydenkin kehityksestä. Maatilan työt loivat miehen työuraan pysyvän juonirakenteen, joka vakautti palkkatyön heiluntaa.

Hahmoton työura ja kompleksinen terveysura

Monen haastatellun työurassa oli huomattavaa kompleksisuutta, joten hahmottoman työuran erottaminen omaksi työuramallikseen oli hankalaa. Erityisesti limittyneisyyttä oli hahmottomissa työurissa ja hahmonsa löytävissä monimutkaisissa työuramalleissa. Ero näiden 
välille määritettiin siihen, että hahmonsa löytävästä mallista oli havaittavissa jokin logiikkaa ja jatkuvuutta tuottava tekijä, attraktori. Sen sijaan hahmoton työura eteni totaalisempien siirtymien kautta. Hetkittäin työuralta saattoi löytyä attraktoreita, mutta ne katkeilivat ja vaihtuivat.

Haastatteluista löytyi kaksi hahmotonta työuraa. Työkyvyttömyyseläkkeelle lopulta päätynyt haastateltu ehti työuransa aikana käydä monenlaisia kouluja ja kursseja sekä toimia useissa ammateissa ja tehtävissä. Käänteitä oli paljon ja pitkäjänteisyyttä vähän.

Yhdessä työuran kohdassa haastatellulla oli ollut selkeä tavoite korkeasta asemasta, jolloin näkyvissä oli suoraviivaisen työuran piirteitä. Tavoitellun aseman saavuttamiselle tuli kuitenkin esteitä.

”Mä vähän jo näin itteni siellä paikalla. ... Kenkää tuli, mutta siinä samalla tosiankin leimattiin $[\ldots]$. Se romutti mun elämän ja mun maailman aika rankasti."

Erityisesti kyseisen tapauksen jälkeen haastateltu alkoi kärsiä monenlaisista terveysongelmista. Edelleen hän kuitenkin kokeili useita ammatteja. Nämäkään työtehtävät eivät ottaneet tulta pidemmäksi aikaa ja aiheuttivat myös terveysongelmia.

"Olin siinä jo jonkun aikaa tehny huonolla selällä töitä, sehän on hirveetä hommaa toi [anonymisoitu]. Ja sitten kun mä sain tiedon siitä, että mä en sitäkään paikkaa saa, sit mä menin lääkäriin ja siitä sitten alko semmonen. Miten mä nyt sanosin sairaus- tai hoitojakso, joka on sitten johtanut siihen, että mä oon nyt eläkkeellä."

Lopulta miehellä oli useita diagnooseja, joista huolimatta hän koki voivansa varsin hyvin. Terveys ei ollut yksiselitteinen asia, mutta tilanne oli miehen hallinnassa.

"Mä oon hoitanut itteni lopullisesti kuntoon."

Mies pohti, että jos elämä olisi mennyt vain hiukan toisin yksittäisissä kohdissa, hänestä olisi voinut tulla NHL-pelaaja tai rajavartija. Hän kertoi useammista elämänsä "kohtalonhetkistä". Pienet valinnat tai ulkopuoliset tekijät olivat haastateltavan mielestä muokanneet hänen elämäänsä perustavanlaatuisesti.

$\begin{array}{ll}\text { "Mun jääkiekkourani } & \text { tyrehtyi, } \\ \text { mahdollinen NHL-urani } & \text { tyrehtyi, } \\ \text { markkaan } 50 \text { penniin." } & \end{array}$ Miehen taloudellinen tilanne oli vaihdellut suuresti. Hän kertoi työuransa parhaimpina aikoina olleensa hyvin toimeentuleva. Nyt mies kärsi taloudellisista vaikeuksista, joita hän kertoi hallitsevansa asuinpaikkavalinnoilla.

"Sitä ei ymmärretä mun mielestä ollenkaan sitä, kuinka ratkasevassa asemassa moniin asioihin on se, että missä kunnossa on kunkin ihmisen talous. Se ratkasee terveyttä, se ratkasee siis koko elämää niin paljon.”

Kokonaisuudessaan haastatellun työura oli varsin monipolvinen, kuten myös erilaisia sairauksia sisältänyt terveysura. Oli ylä- ja alamäkiä sekä erilaisia vaihdoksia. Ennenaikaiseen eläköitymiseen työuraa ajoivat sekä työelämässä kohda- 
tut vaikeudet että terveyden vaikeudet yhteen kietoutuneina. Työn ja terveyden vaihdosten ohella taloustilanne vaihteli hyvin toimeentulevasta taloudellisissa vaikeuksissa painiskelevaan. Monimutkaisella ja hahmottomalla työuralla oli haastatellun tapauksessa seuralaisenaan samankaltainen terveysura. Valinnanmahdollisuudet olivat rajalliset, vaikka vaihtoehtoja oli riittänyt.

\section{YHTEENVETO JA JOHTOPÄÄTÖKSET}

Tutkimuksemme perusteella moninaisia kontekstitekijöitä, kytköksiä ja dynamiikkoja yksilön valinnanvapauden sijasta korostava sekä erilaisia työuramuotoja ja niiden vaihteluja tunnistava työurien kaaosteoria tarjoaa vaihtoehdon työurien tutkimiseen muuttuvassa työelämässä. Vaikka aineistomme oli pieni ja vain Pohjois-Karjalan miehistä koostuva, siitä löytyi kaikkia aiemmissa tutkimuksissa esitettyjä työuran muotoja eli suoraviivainen työura, heilurimallinen työura, hahmonsa löytävä työura sekä hahmoton työura (Pryor \& Bright 2014). Nämä tosin limittyivät. Tapauksista löytyi mallien väliin asettuvia muotoja sekä työuria, joilta löytyi erilaisten attraktorimallien vaiheita ja siirtymiä. Heilurimallisesta työurasta löysimme versiot, joista toisesta muodostui tasapainoinen ja täydentävä ja toisesta ristivetoinen ja repivä. Lisäksi repivästä heilurista löytyi myös malli, jossa heilurin toisen pään muodosti olemassa olevan vaihtoehdon sijasta käsistä karkaava haavekuva.

Suoraviivainen, lineaarinen työura yksiselitteisine katkoskohtineen on usein taustaoletuksena yhteiskunnallisessa työurakeskustelussa ja po- liittisessa päätöksenteossa. Jo tähän yksinkertaisimpaan työuramuotoon muodostui aineistossamme monen suuntaisia vapaata valintaa rajaavia vaikutussuhteita työn, terveyden ja talouden kytkeytyessä toisiinsa. Rationaalista valintaa tyypillisempää oli uran muotoutuminen erilaisten sattumien ja onnenkantamoisten summaksi (vrt. Resnicow \& Page 2008).

Aineiston monimutkaisemmissa työuramuodoissa tuli esiin useampien ammattien ja tehtävien limittyminen eli lisääntymässä olevaksi ennakoitu monityösuhteisuus (Järvensivu 2014). Nämä työuramuodot kehkeytyivät monien tekijöiden vaikutuspiirissä. Edes jatkuvuuksia muodostavat työt eivät välttämättä olleet yksilön rationaalisia valintoja. Pohjois-Karjalan miehille tyypillinen oli heidät sukupolvien ketjuun kytkevä velvollisuus tai halu ylläpitää kotitilaa muiden töiden ohella. Heilurimalliset työurat, hahmonsa löytävät ja hahmottomat työurat toivat näkyväksi kontekstitekijöiden sekä erilaisten takaisinkytkentöjen ja monimutkaisten seurausvaikutusten merkityksen työurille (vrt. Amundson ym. 2014; Bryor \& Bright 2012; 2014).

Haastateltujen terveyskokemusten suhteuttaminen työuramalleihin osoitti, että työurat ja terveysurat kietoutuivat vahvasti ja moninaisin tavoin toisiinsa. Terveyden käänteet vaikuttivat työhön ja työn terveyteen, samaan tapaan kuin Hiilamo ym. (2011) ovat havainneet huono-osaisuuden ja sairastavuuden osalta. Toisinaan vaikutussuhteet olivat myönteisiä, toisinaan kielteisiä, joskus yhtä aikaa kummankinlaisia. Vahvana tekijänä työn ja terveyden välissä vaikuttivat taloudelliset huolet. Ne saattoi- 
vat estää tai pakottaa valintoja toiveista ja haluista riippumatta.

Työura ja terveysura kulkivat siinä määrin yhdessä, että eri työuramalleja vastaavat terveysuramallit saattaisivat olla löydettävissä, mikä olisi kiinnostava jatkotutkimuskohde. Myös heilurimallisen työuran kaksi variaatiota vaikuttivat kytkeytyvän omanlaisiinsa terveysmalleihin. Repivä heiluriliike näyttäisi repivän terveyttä, kun taas täydentävä malli saattaisi edistää terveyttä. Työuramalleja ja työ- ja terveysuran kytkeytymistä olisi tarkasteltava toisenlaisissa kohdejoukoissa ja toisenlaisin metodein.

Työurien analysointi kaaosteorian avulla toi esiin työurien muotojen moninaisuuden, työurien vähäisen suunnitelmallisuuden ja rajallisen valinnanvapauden sekä kontekstin, kytkösten, dynamiikkojen ja sattumien merkityksen uran kehkeytymiselle. Tutkimus paljasti työn ja terveyden monimutkaisen ja tiiviin kytkeytyneisyyden, mikä on omiaan vähentämään yksilön valinnanvapauksia ja -mahdollisuuksia. Jatkossa olisi kiinnostavaa tarkastella muiden tekijöiden, kuten perheen, sosiaalisten suhteiden, sosio-ekonomisen aseman, iän ja elämänvaiheen sekä alueen kytköksiä ja dynamiikkoja työuran kehkeytymisessä sekä eri työuramallien esiintyvyyttä ja muutoksia työelämän muuttuessa.

Tulevaisuuden työelämän piirteeksi on toistuvasti nimetty suoraviivaisten yhteen osaamiseen ja ammattiin perustuvien työurien väheneminen. Tilalle on ennakoitu tulevan monimutkaisempia urapolkuja siirtymineen. Ihmisen on muuttuvassa työelämässä pärjätäkseen rakennettava useammanlaisista osaamisalueista harvinaisia yhdistelmiä ja varauduttava siirtymiin uusia osaamisalueita kehittämällä. (Esim. Gratton 2011; Järvensivu 2014; Dufva ym. 2017.) Työurien kaaosteoria mahdollistaa syntyvien erilaisten työuramuotojen havaitsemisen, tarkastelun, analysoinnin ja vertailun. Sen avulla voi jäsentää tulevaisuudessa lisääntyväksi ennakoitua kompleksisuutta tuoreella tavalla. Samalla attraktorin käsite antaa väljyyttä työuralle muotoa tuottavien tekijöiden, logiikoiden, jatkuvuuksien ja kiinnekohtien määrittelyyn.

Kun työura ja sen muoto ajatellaan kontekstissaan kehkeytyväksi sen sijaan, että ura perustuisi ihmisen pitkäjänteiseen suunnitelmalliseen tavoitteellisuuteen ja kykyyn hallita ympäristönsä tapahtumia, myös työuraa tukevat toimet alkavat näyttää toisenlaisilta. Proaktiivinen vaihtoehtojen rakentaminen, avautuvien mahdollisuuksien huomaaminen ja niihin tarttuminen tulevat tärkeiksi. Vaihtoehtojen rakentumisen kannalta ihmisen ja hänen työuransa konteksti on merkityksellinen: PohjoisKarjalan 60-luvulla syntyneiden miesten työurat kehkeytyvät toisenlaisessa ympäristössä kuin pääkaupunkiseudun 80-luvulla syntyneiden naisten. Edellisten kohdalla korostuva kulttuurinen sidos kotitilan maa- ja metsätöihin tuskin muodostaa merkityksellistä attraktorin osaa jälkimmäisten joukossa.

Työ- ja sosiaalipolitiikan kannalta edellinen tarkoittaa vakaan ja ennakoitavan taloudellisen perustan varmistamista sekä lineaarisesta työuraoletuksesta luopumista, sillä ihminen on tulevaisuudessa yhä harvemmin yksiselitteisesti yrittäjä, palkansaaja, työtön, opiskelija 
tai eläkkeellä. Toisaalta tapauskohtainen ohjaus korostuu, sillä työuraa kannattelevat ja eteenpäin kuljettavat tekijät pitäisi tunnistaa jokaisen kohdalta erikseen. Onnistuneelta koulutuspolitiikalta voisi edellyttää taipuisuutta nopeasti ja helposti saatavilla oleviin lisä- ja uudelleenkoulutuksiin.

Tällä hetkellä politiikkatoimien onnistumiseen ja vastaanottoon saattaa vaikuttaa ihmisen irrottaminen ympäristöstään, atomistinen individualismi (Taylor 1995), yliautonomisointi (Pulkki ym. 2015) ja lineaarisen työuran oletus. Esimerkiksi työttömyyden vähentämiseksi tarkoitetun aktiivimallin tammikuussa 2018 kohtaama raju vastustus johtui osaltaan siitä, että kansalaiset kokivat mallin perustuvan yliautonomisoituun kuvaan ihmisestä valitsijana, kun samaan aikaan arkisessa todellisuudessa työmarkkinat ja työuran rakentaminen muuttuvat yhä kompleksisemmiksi. Tässä esitettyjä työuramalleja ja niiden mahdollistamia luokituksia saattaisi olla hedelmällistä jatkotutkimusten jälkeen soveltaa niin aktiivimallin kaltaisten poliittisten toimien edelleen kehittämiseen kuin henkilökohtaisten työllistymistä tukevien suunnitelmien tekemiseenkin. Ihmisen työuramuodon tunnistaminen voisi toimia pohjana henkilökohtaiselle ohjaukselle.

Kiitämme Koneen Säätiötä rahoituksesta sekä erikoistutkija Lauri Kokkisen (TTL) johtamaan Terveyden luokkakuva -hankkeeseen osallistuneita muita tutkijoita hyvästä yhteistyöstä.

\section{KIRJALlisuUs}

Aaltonen, Tarja \& Leimumäki, Anna (2010) Kokemus ja kerronnallisuus - kaksi luentaa. Teoksessa Johanna Ruusuvuori, Pirjo Nikander \& Matti Hyvärinen (toim.) Haastattelun analyysi. Tampere: Vastapaino. 119-152.

Alasoini, Tuomo (2017) Joukkoistettu työ niche-innovaationa... ja työsuhderegiimin murtajana? Monitasomalliin perustuva analyysi. Työelämän tutkimus, 15(3), 266-280.

Alasuutari, Pertti (2011) Laadullinen -tutkimus 2.0. Tampere:Vastapaino.

Amundson, Norman \& Mills, Lauri \& Smith, Barbara (2014) Incorporating chaos and paradox into career development. Australian Journal of Career Development 23 (1), 13-21. https://doi. org/10.1177/1038416213496760

Beurden van, Erik \& Kia, Annie \& Zask, Avigdor \& Dietrich, Uta \& Rose, Lauren (2011) Making sense in a complex landscape: how the Cynefin Framework from Complex Adaptive Systems Theory can inform health promotion practice. Health Promotion International 28 (1), 73-83.

Diez Ruox, Ana (2011) Complex Systems Thinking and current impasses in health disparities research. American Journal of Public Health 101 (9), 1627-1634. https://doi.org/10.2105/ AJPH.2011.300149

Dufva, Mikko \& Halonen, Minna \& Kari, Mika \& Koivisto, Tapio \& Koivisto, Raija \& Myllyoja, Jouko (2017) Kohti jaettua ymmärrystä työn tulevaisuudesta. Valtioneuvoston selvitys- ja tutkimustoiminnan julkaisusarja 33/2017. http:// tietokayttoon.fi/julkaisu?pubid=18301. Luettu 25.12.2017.

Campbell, Shelagh (2012) Comparative Case Study. Teoksessa: Albert Mills, Gabrielle Durepos \& Elden Wiebe (toim.) Encyclopedia of Case Study Research. Thousand Oaks: SAGE Publications.

Fink, David \& Keyes, Katherine \& Cerdá, Magdalena (2016) Social determinants of population health: a systems science approach. Current Epidemiology Reports 3 (1), 98-105. https://doi.org/10.1007/ 
s40471-016-0066-8

Frey, Carl \& Osborne, Michael (2013) The future of employment: How susceptible are jobs to computerization? https:// www.oxfordmartin.ox.ac.uk/downloads/academic/The_Future_of_Employment.pdf. Luettu 6.8.2017.

Goodrick, Delwin (2014) Comparative Case Studies, Methodological Briefs: Impact Evaluation 9. Florence: UNICEF Office of Research.

Gratton, Lynda (2011) The Shift. The future of work is already here. London: Collins.

Hechter, Michael \& Kanazawa, Satoshi (1997) Sociological rational choice theory. Annual Review of Sociology 23, 191214. https://doi.org/10.1146/annurev. soc. 23.1 .191

Hiilamo, Heikki \& Hänninen, Sakari \& Kinnunen, Kaisa (2011) Huono-osaisuuden ja sairastavuuden kytkennästä diakonian asiakkailla. Sosiaalilääketieteellinen Aikakauslehti 48 (1), 4-21.

Järvensivu, Anu (2010) Tapaus työelämä ja voiko sitä muuttaa? Tampere: Tampere University Press.

Järvensivu, Anu (2014) Tarinoita suomalaisesta työelämästä. Helsinki:Työterveyslaitos.

Kansalaisaloite 2730. https://www.kansalaisaloite.fi/fi/aloite/2730 Luettu 12.1.2018.

Marttila, Liisa (2015) Ura kerronnallisena työnä. Ammattikorkeakoulun opettajat kertojina. Acta Universitatis Tamperensis 2058. Tampere:Tampere University Press.

Mingers John \& White, Leroy (2010) A review of the recent contribution of systems thinking to operational research and management science. European Journal of Operational Research 207 (3), 1147-1161. https://doi.org/10.1016/j. ejor.2009.12.019

Pulkki, Jani \& Saari, Antti \& Pulkki, Jutta \& Värri Veli-Matti (2015) Vapaus, valta ja vastuuterveydenhuollossa - Yhteiskuntafilosofinen näkökulma. Teoksessa Mikko Niemelä, Lauri Kokkinen, Jutta Pulkki, Arttu Saarinen \& Liina-Kaisa Tynkkynen (toim.) Terveydenhuollon muutokset. Tampere: Tampere University Press. 154-170.
Pryor, Robert \& Bright, Jim (2012) The value of failing in career development: a chaos theory perspective. International Journal for Educational and Vocational Guidance, 12, 67-79. https://doi. org/10.1007/s10775-011-9194-3

Pryor, Robert \& Bright, Jim (2014) The Chaos Theory of Careers (CTC): Ten years on and only just begun. Australian Journal of Career Development 23 (1), 4-12. https://doi. org/10.1177/1038416213518506

Pärnänen, Anna \& Sutela, Hanna (2014) Itsensätyöllistäjät Suomessa 2013. Helsinki: Tilastokeskus.

Pyöriä, Pasi (toim.) (2017) Työelämän myytit ja todellisuus. Helsinki: Gaudeamus.

Resnicow, Kenneth \& Page, Scott (2008) Embracing Chaos and complexity: A quantum Change for Public Health. American Journal of Public Health 98 (8), 1382-1389. https://doi.org/10.2105/ AJPH.2007.129460

Taloussanomat 16.2.2017. 50000 miestä parhaassa iässä ei tee töitä tai opiskele - "Mitä heille tapahtui?" http://www. is.fi/taloussanomat/art-2000005090057. html Luettu 16.5.2017.

Taloussanomat 13.12.2016. Nuorista miehistä liki viidennes ei tee töitä eikä opiskele - "Hälytyskellojen pitäisi soida" http://www.is.fi/taloussanomat/art2000005005604.html Luettu 16.5.2017.

Taylor, Charles (1995) Autenttisuuden etiikka. Helsinki: Gaudeamus.

Tuomi, Jouni \& Sarajärvi, Anneli (2002) Laadullinen tutkimus ja sisällönanalyysi. Jyväskylä: Gummerus.

Ratkaisujen Suomi. Pääministeri Juha Sipilän hallituksen strateginen ohjelma 29.5.2015. Hallituksen julkaisusarja 10/2015. http://valtioneuvosto.fi/documents/10184/1427398/ Ratkaisujen+Suomi_FI_YHDISTETTY_netti.pdf/801f523e-5dfb-45a48b4b-5b5491d6cc82 Luettu 16.5.2017. 